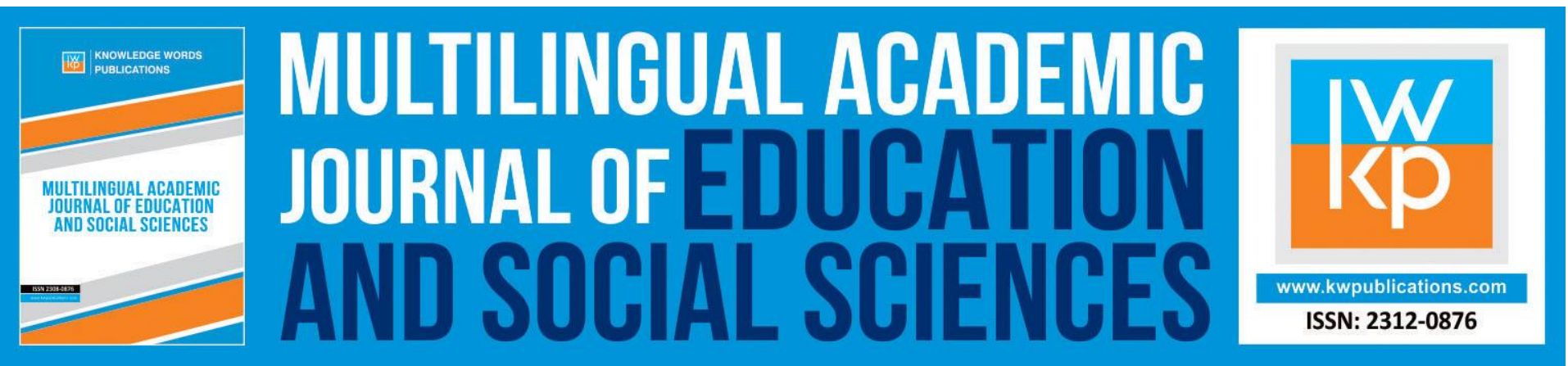

\title{
An Intervention Program Related to Reading Development: A Case Study of a Child with Williams Syndrome
}

\author{
Anastasia Alevriadou, Maria Massi
}

To Link this Article: http://dx.doi.org/10.46886/MAJESS/v1-i1/7291

DOI: 10.46886/MAJESS/v1-i1/7291

Received: 07 January 2013, Revised: 23 February 2013, Accepted: 04 March 2013

Published Online: 17 April 2013

In-Text Citation: (Alevriadou \& Massi, 2013)

To Cite this Article: Alevriadou, A., \& Massi, M. (2013). An Intervention Program Related to Reading Development - A Case Study of a Child with Williams Syndrome. Multilingual Academic Journal of

Education and Social Sciences, 1(1), 86-100.

Copyright: ( ) The Authors 2013

Published by Knowledge Words Publications (www.kwpublications.com)

This article is published under the Creative Commons Attribution (CC BY 4.0) license. Anyone may reproduce, distribute, translate and create derivative works of this article (for both commercial and non-commercial purposes), subject to full attribution to the original publication and authors. The full terms of this license may be seen

at: $\underline{\text { http://creativecommons.org/licences/by/4.0/legalcode }}$

Vol. 1, No. 1, 2013, Pg. 86 - 100

https://kwpublications.com/journals/journaldetail/MAJESS

JOURNAL HOMEPAGE

Full Terms \& Conditions of access and use can be found at https://kwpublications.com/pages/detail/publication-ethics 


\title{
An Intervention Program Related to Reading Development: A Case Study of a Child with Williams Syndrome
}

\author{
Anastasia Alevriadou, Maria Massi \\ University of Western Macedonia, Greece
}

\begin{abstract}
The present paper is related to a case study of an 8-year-old girl with Williams syndrome and mild intellectual disability. Initial informal assessments and standardized tests indicated that her reading ability was underdeveloped, as well as her phonological awareness. Hence, an intervention for the development of reading skills was designed according to the principles of the 'top-down' educational model, combining features from several teaching methods, such as 'holistic approach', 'holistic-analytical method', and 'whole-word teaching'. The student's progress was recorded in the researcher's journal and evaluated through informal continuous assessment and standardized test. She managed to read 45 out of 65 words, which were included in the intervention, simple syllables with the consonant-vowel sequence and some simple twosyllable words without any complex content, not included in the intervention. The intervention proved to be effective, as the student indicated development in her reading skills, although to a certain degree. Finally, the results verified the influence of the phonological factor in reading and highlighted the holist approach as an appropriate way to develop reading and comprehension skills.
\end{abstract}

Keywords: Williams Syndrome, Reading Ability, Educational Reading Program, Intervention, Language Skills.

\section{Introduction}

Williams syndrome (WS) is a rare (1:7500 births) neurodevelopmental disorder, caused by deletion of a segment in chromosome 7q11.23, which includes about 25 genes, and is characterized by typical facial dysmorphology, mental retardation and congenital cardiovascular difficulties. WS is associated with a specific cognitive profile, including relatively preserved linguistic and social skills in contrast to impaired spatial and motor skills (Stromme et al., 2002).

Individuals with WS have developmental delay which leads to intellectual disability and learning difficulties. Several standardized measures, such as Wechsler Intelligence Scales and Kaufman Brief Intelligence Test - K-BIT point out a high prevalence of mental retardation within the mild to moderate interval (Herwegen et al., 2011). 
MULTILINGUAL ACADEMIC JOURNAL OF EDUCATION AND SOCIAL SCIENCES

Vol. 1 No. 1, 2013, E-ISSN: 2308-0876 @ 2013 KWP

Language is often considered as a 'strong' area in the WS phenotype, since children with this syndrome are capable of producing fluent, easily understood and expressive speech, using extensive vocabulary, as well as able to enrich their communication with several prosodic cues. Nevertheless, their linguistic development is almost always delayed from the very beginning, as they usually start acquiring language around the age of 28 months (Marini et al., 2010). Thus, their language skills and abilities are not compatible with the general level of their cognitive abilities (Pleh et al., 2003; Stojanovik, 2010). Although they show brilliant expressive skills, which is usually a misleading aspect, they indicate inefficient and inappropriate language comprehension skills, both at pragmatic and semantic level (Mervis et al., 2003).

It has been widely acknowledged that, individuals with WS have rather an impressive vocabulary range, compared to other genetic syndromes, although vocabulary acquisition occurs at a rather slow rate, usually after the age of six (Stojanovik \& Ewijk, 2008; Ypsilanti et al., 2005).

Although the language of individuals with WS comprises a wide range of vocabulary, it is of low pragmatic quality. Indeed, they often use clichés and idioms, as well as unusual and bizarre words, engendering the phenomenon of the "cocktail party speech" (Mervis and Becerra, 2007; Temple et al., 2002). Deficits related to pragmatics are obvious during discussions and narrations too, as they usually fail to maintain the topic and adhere to the conversational context, giving inappropriate and incomplete answers (Rossi et al., 2011).

Despite the fact that reading is expected to be a rather unimpaired skill of individuals with WS (Porter \& Dodd, 2011), reading achievements of children with WS remain poor, due to individual differences in intelligence and phonological skills (Laing et al., 2001; Mervis, 2009).

Although children with WS respond relatively well on word decoding, they encounter difficulties in reading comprehension (Laing et al., 2001), likely because of the lack of semantic activation or the irregular semantic processing while reading. Instead, reading is performed mainly through the phonological processing of the written information, by only creating mappings between orthography and phonology and not between orthography and semantics (Laing et al., 2001). Thus, the impact of semantic factor on reading is taken into consideration, since it has been claimed that individuals with WS encounter difficulties in reading pseudo-words or tend to convert them to real words (Barca et al., 2007; Menghini et al., 2004). Additionally, they indicate deficient phonological decoding and inefficient relationship between the phonemes and the graphemes (Pinheiro et al., 2010).

The debate concerning reading process and the contribution of the phonological versus semantic factor to the processing of the written information has resulted into identifying an appropriate method to teach reading to children with WS. A number of researchers supported the idea that words are initially formed from component letters (e.g. analytical model, Forster, 1976), while others highlight the advantages of holistic model, where words can be formed either via letter-level codes (as in analytical models) or via word-level codes. Teaching reading through phonics is proposed by the supporters of the 'phonological factor' (Becerra et al., 2008; Levy \& Antebi, 2004; Mervis, 2009), while teaching reading by employing holistic approach is proposed by the supporters of the 'semantic factor' (Menghini et al., 2004).

The aim of the present case study was to develop reading skills of a child with WS, by implementing reading intervention which followed an appropriate and effective method. 
MULTILINGUAL ACADEMIC JOURNAL OF EDUCATION AND SOCIAL SCIENCES

Vol. 1 No. 1, 2013, E-ISSN: 2308-0876 @ 2013 KWP

Method

The Participant

The participant of this study was an 8-year-old girl with WS, who attended the second grade of primary school. Clinical features, such as intellectual disability and elfin face, indicate the existence of the syndrome. She also suffered from heart disease, faced language difficulties, as well as difficulties in fine motor skills. Her one-year-younger brother and her parents did not experience any medical, genetic or learning problems. She was born in a natural way, however during the first years of her life, a developmental delay was identified, especially regarding speech and motor development. She has been diagnosed as WS, at the age of 4, by proper genetic tests, at the hospital. The girl had already been involved in speech and occupational therapy therapy sessions.

Wechsler Intelligence Scale for Children III (WISC-III) was used the evaluation of her intelligence (Georgas et al., 1998). The girl was diagnosed as an individual with mild intellectual disability, with no statistically important deviation between Verbal and Performance IQ.

\section{Assessment Instruments}

Before the intervention, student's cognitive skills and general abilities were identified through informal assessments, as well as through standardized typical methods.

- Raven's Colored Progressive Matrices Test: Her cognitive abilities were assessed by using Raven's Colored Progressive Matrices Test. Her mental age was 6 years (Raven et al., 1990).

- Informal assessment of the abilities regarding written language and phonological awareness: The assessment included several tasks with letters, such as "Circle the letters you hear", "Read the letters you see", "Join the capital with the small letters", "Rewrite the letters you see", "Write the letters you hear", tasks with syllables, such as "Read the syllables", "Rewrite the syllables", "Write the syllables you hear", as well as tasks with words. The student performed successfully the letter-tasks, as she was able to recognize each letter, detect the letter among others, distinguish capital and small letters, rewrite and write letters alone. As for the syllable-tasks, the student could read the syllables given, except for syllables with ligatures or other letter combinations. Nevertheless, she only read the syllables by pronouncing each phoneme separately, thinking a while and then pronouncing their combination.

- The evaluation of her phonological awareness was carried out through several tasks, detecting her ability to handle individual phonological units in the word. She was asked to find the first or the last phoneme of a word, to recognize the word after combining its syllables or phonemes, to analyze the word to its syllables or phonemes, to find words by first/last syllable/phoneme given, to invert a pair of phonemes. The student encountered difficulty in phonological tasks, as she could only find the first phoneme in case of vowel (in case of consonant, she repeated the whole first syllable), she couldn't find the last phoneme at all, nor could she invert the phoneme pairs given. She could combine the syllables given, but not associate the word to them, nor could handle the phonemes. She could find a word by the first syllable or phoneme given, but not by the last.

- Standardized screening test of identifying reading difficulties: The student was examined by the standardized "Test of Identifying Reading Difficulties" (Porpodas et al., 2008), 
MULTILINGUAL ACADEMIC JOURNAL OF EDUCATION AND SOCIAL SCIENCES

Vol. 1 No. 1, 2013, E-ISSN: 2308-0876 ¿ 2013 KWP

which included tasks related to reading decoding, reading comprehension, phonological awareness and phonological short-term memory. The participant's performance in each area was sufficient enough to place her on the lower scale.

\section{The Intervention}

The individual intervention programme, which was designed with the aim to help the eight-years-old girl develop reading skills, followed a multimethodological and multisensory approach combining elements from several methods, such as 'holistic approach', 'holisticanalytical method', 'whole-word teaching'. The intervention adopted the principles of the 'topdown' educational model, in respect of constructing the knowledge.

\section{Material Design}

The reading material was constituted from 12 thematic axes, with 5 words in each, related to the girl's everyday life (fruits, animals, vegetables, means of transport, body parts, actionverbs, school supplies, weather, nature, foods, toys and sense-verbs). The words chosen were two-syllable or three-syllable and more, had simple sequence of consonant-vowel or more complex composition. The material was designed in an attractive way for the student and included cards with pictures and words, carton puzzles, reading wheel, powerpoint presentations and several tasks, where she had to circle the right answer, to find the matching, to fill in with the same color and many others explained below.

\section{Procedure}

The intervention, which lasted for 5 months, was implemented twice a week, for 1 hour. It was carried out through 3 basic stages: the pre-stage, where the new words were presented and the student was prepared to read them, the while-stage, whereby she mainly practiced reading the new words, focusing successively on the sentence-word-syllable-letter (top-down model) and the post-stage, where feedback was provided and the new skills were transferred in an alternative framework. Additionally, revising lessons, after every 4 thematic axes, aimed at recycling vocabulary and student's progress evaluation. Furthermore, information in respect of the intervention procedure, as well as the evaluation of the intervention were recorded in the researcher's journal.

\section{Pre-stage}

- The new 5 words (one thematic axe each time) were at first exhibited through computer.

- The student had to find the proper word, among distracters, and stick it next to the correct pair of picture-word. In other words, she had to rely on similarities.

- The carton puzzle directed the picture-word matching, with proper drivers of the pieces.

- The student had to use the color to fill in the picture and the letters of the word.

- Pairs of cards were used as memory cards, for the picture-word matching without drivers. 
MULTILINGUAL ACADEMIC JOURNAL OF EDUCATION AND SOCIAL SCIENCES

Vol. 1 No. 1, 2013, E-ISSN: 2308-0876 @ 2013 KWP

Table 1. Pre-stage activities

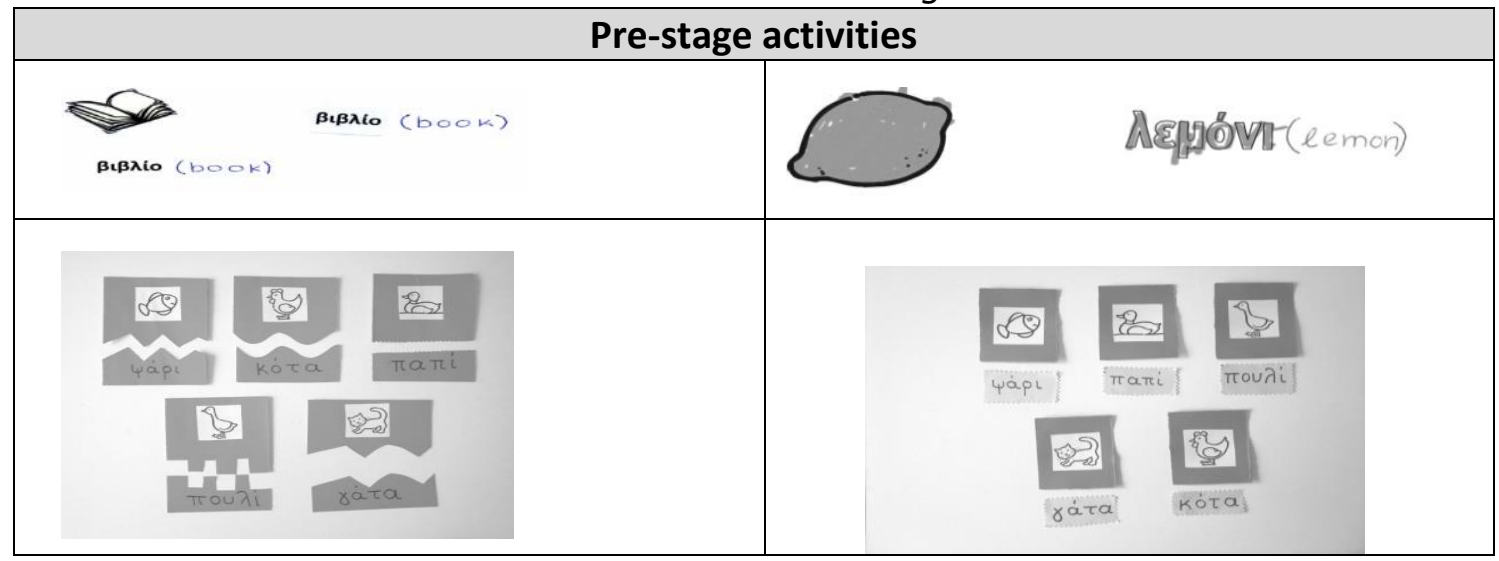

\section{While-stage}

1st phase-sentence

- After reading the sentence by having the researcher's help, she had to detect and circle the word in the sentence.

- The student had to put the proper word back into the sentence.

Table 2. While-stage activities (1st phase-sentence)

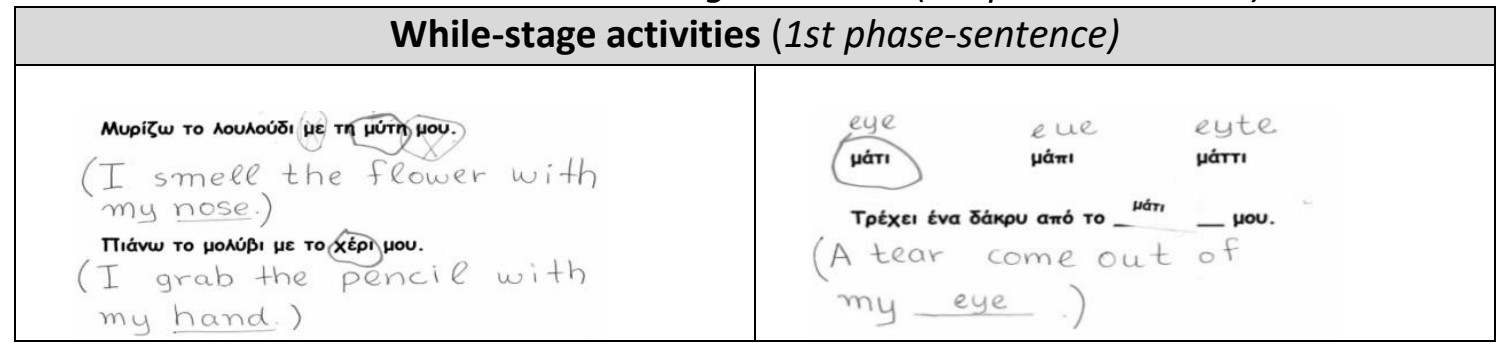

\section{2nd phase-word}

- She had to join with a line the picture with the proper word.

- The girl had to detect and circle the correct word among distracters, looking at the paradigm.

- She had to circle the proper word with no paradigm given. 
MULTILINGUAL ACADEMIC JOURNAL OF EDUCATION AND SOCIAL SCIENCES

Vol. 1 No. 1, 2013, E-ISSN: 2308-0876 @ 2013 KWP

Table 3. While-stage activities (2nd phase-word)

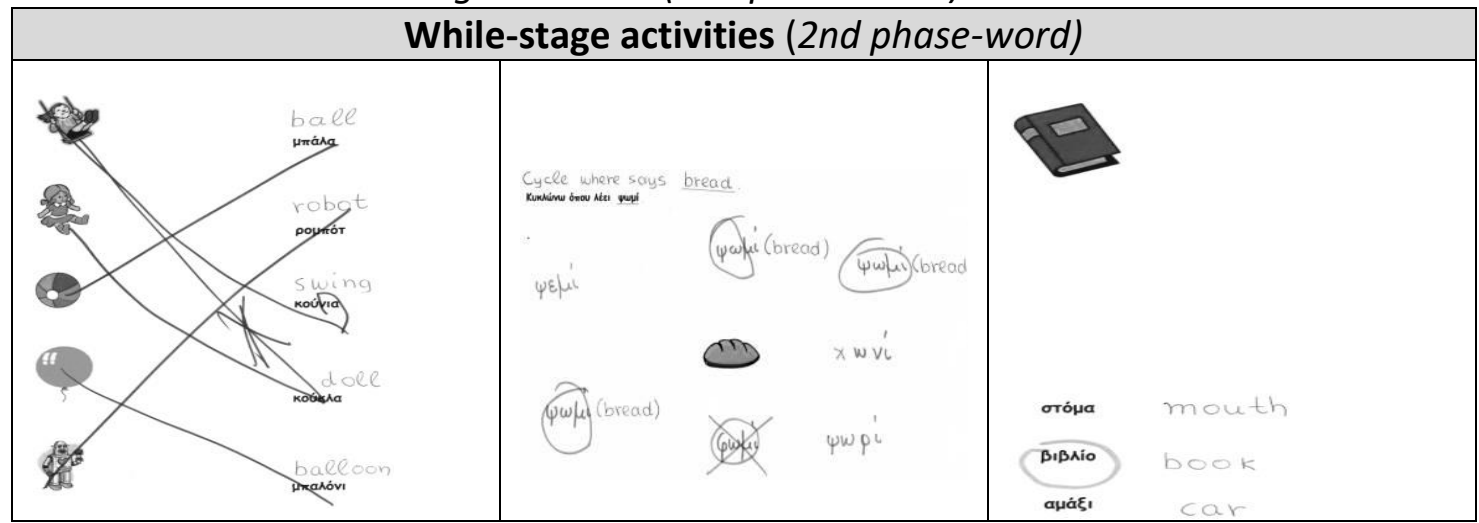

3rd phase-syllable

- After dividing the word into syllables, by clapping her hands, she had to do the same on paper, circling each syllable separately.

- The girl had to put the syllables in the correct sequence to construct the word.

- She had to detect the missing syllable, among others, and put into the word.

Table 2. While-stage activities (3rd phase-syllable)

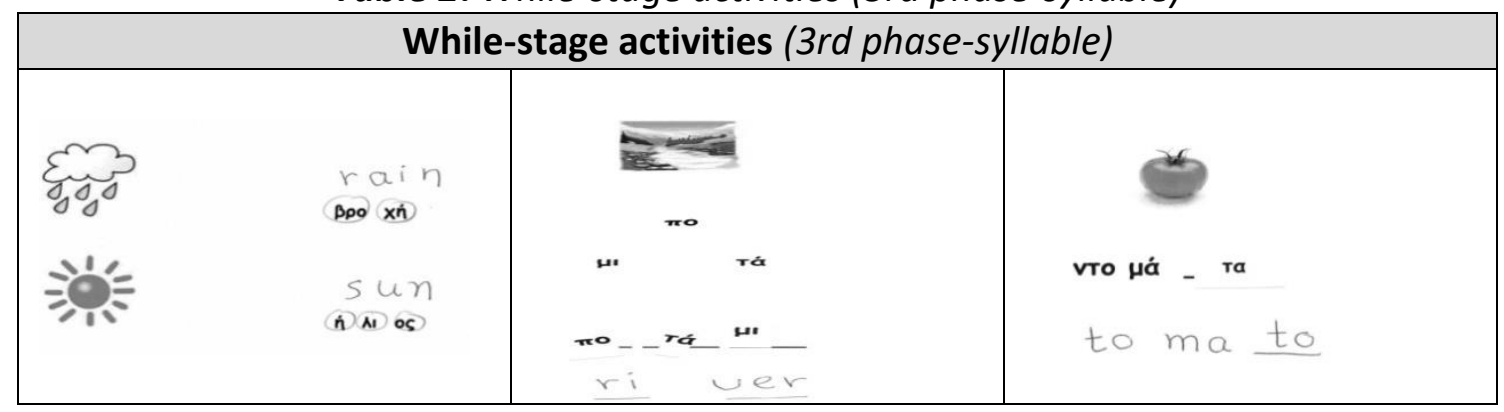

4th phase-letter

- The girl had to join with a line the proper syllables to construct the word, having to choose among syllables differing in one letter.

- She had to circle the correct word, having to choose among words differing in the first and one more letter.

- The student had to circle the correct word, having to choose among words differing in an intervening letter. 
MULTILINGUAL ACADEMIC JOURNAL OF EDUCATION AND SOCIAL SCIENCES

Vol. 1 No. 1, 2013, E-ISSN: 2308-0876 @ 2013 KWP

Table 3. While-stage activities (4th phase-letter)

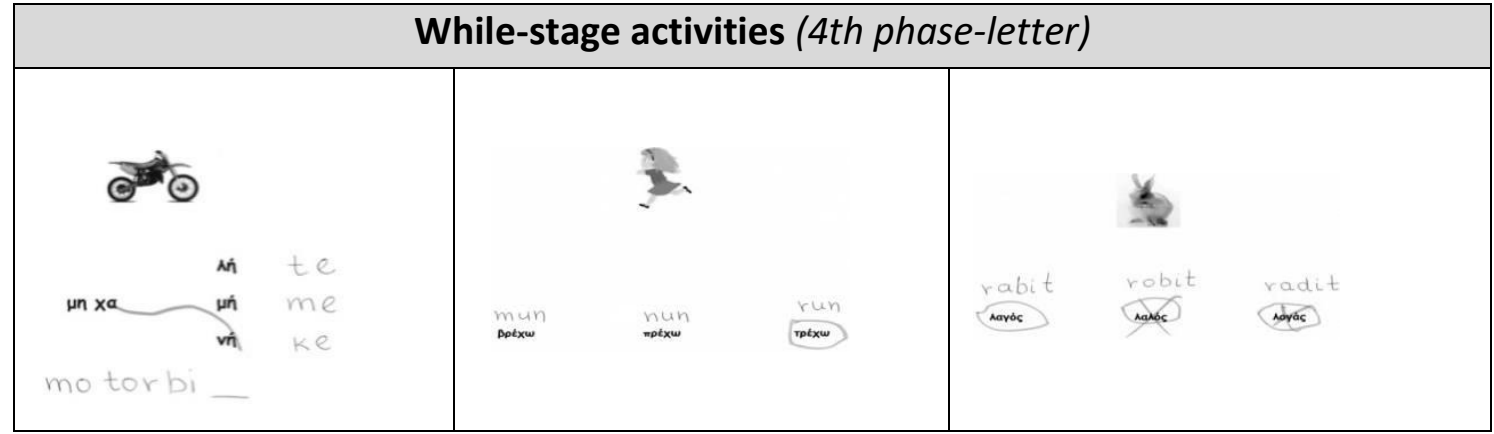

\section{Post-stage}

- The 'reading-wheel', which is a round card with the five words written on top, was given to the student, who was motivated to handle it alone and play with it.

- At the end, the girl was asked to choose one word from each group and draw or write something relevant.

Table 4. Post-stage activities

\begin{tabular}{|l|l|}
\hline Post-stage \\
\hline xioontripia ipyava \\
\hline
\end{tabular}

\section{Results}

Researcher's journals: A lot of information was extracted from journals that included data regarding the procedure of the intervention and the purpose of each thematic axe. A variety of teaching aids were used, which attracted student's interest, like puzzle, colors, cards and others, as well as various teaching techniques, like playing, computer use, memory recall, mimic, sensory approach and feedback. The eight-year-old girl showed a positive attitude towards intervention, willing participation and interest in playing with the new material, most of the times. She encountered difficulties in long or similar words, words with complex phonetic combinations, especially in the 4th phase-letter of the while-stage, which issues demanding perception of very slight differences between words. Nevertheless, the student achieved the learning goals for most of the thematic axes. 
MULTILINGUAL ACADEMIC JOURNAL OF EDUCATION AND SOCIAL SCIENCES

Vol. 1 No. 1, 2013, E-ISSN: 2308-0876 @ 2013 KWP

Table 7: Categorized information of the diaries

\begin{tabular}{|c|c|c|c|}
\hline Typology & Categories & Subcategories & Frequency \\
\hline \multirow{13}{*}{$\begin{array}{l}\text { A. } \\
\text { Intervention } \\
\text { al procedure }\end{array}$} & The purpose & $\begin{array}{l}\text { visual recognition } \\
\text { of the words }\end{array}$ & 12 \\
\hline & & Computer & 12 \\
\hline & & Puzzle & 12 \\
\hline & Techniques and & $\begin{array}{l}\text { several activities on } \\
\text { paper }\end{array}$ & 12 \\
\hline & activities & colors & 12 \\
\hline & & matching cards & 12 \\
\hline & & reading wheel & 12 \\
\hline & & Play & 12 \\
\hline & & use of the & 12 \\
\hline & Teaching & computer & \\
\hline & approaches & memory recall & 12 \\
\hline & & mimic & 12 \\
\hline & & $\begin{array}{l}\text { multisensory } \\
\text { approach }\end{array}$ & 12 \\
\hline \multirow{18}{*}{$\begin{array}{l}\text { B. The } \\
\text { student }\end{array}$} & & feedback & 11 \\
\hline & & positive attitude & 9 \\
\hline & & neutral attitude & 3 \\
\hline & & active role & 10 \\
\hline & & active role after & 2 \\
\hline & Student's attitude & motivation & \\
\hline & towards & much interest & 3 \\
\hline & intervention & $\begin{array}{l}\text { confidence with the } \\
\text { material }\end{array}$ & 6 \\
\hline & & bad mood & 3 \\
\hline & & disappointment & 4 \\
\hline & & $\begin{array}{l}\text { when doing } \\
\text { mistakes }\end{array}$ & \\
\hline & & powerpoint & 12 \\
\hline & Favourite & presentations & \\
\hline & techniques/activiti & play with cards & 12 \\
\hline & es & activities with glue & 12 \\
\hline & & pictures with horses & 1 \\
\hline & & $\begin{array}{l}\text { attention deficits } \\
\text { problems }\end{array}$ & 12 \\
\hline & Difficulties & $\begin{array}{l}\text { 4th phase-letter of } \\
\text { the while-stage } \\
\text { activities }\end{array}$ & 11 \\
\hline
\end{tabular}


MULTILINGUAL ACADEMIC JOURNAL OF EDUCATION AND SOCIAL SCIENCES

Vol. 1 No. 1, 2013, E-ISSN: 2308-0876 @ 2013 KWP

\begin{tabular}{|c|c|c|c|}
\hline & & long words & 2 \\
\hline & & semantic & 2 \\
\hline & & comprehension & \\
\hline & & words with complex & 4 \\
\hline & & phonetic & \\
\hline & & combinations & \\
\hline & & achieving learning & 8 \\
\hline & The objectives & goal & \\
\hline & & $\begin{array}{l}\text { failure to achieve } \\
\text { learning goal }\end{array}$ & 4 \\
\hline C. & & frequent & 11 \\
\hline $\begin{array}{l}\text { Estimation } \\
\text { of the }\end{array}$ & & $\begin{array}{l}\text { disruptions of the } \\
\text { teaching }\end{array}$ & \\
\hline intervention & & attention problems & 11 \\
\hline & & insufficient time & 9 \\
\hline & & difficulties because & 6 \\
\hline & Problems & $\begin{array}{l}\text { of the sequence of } \\
\text { the issues }\end{array}$ & \\
\hline & & slow rate & 1 \\
\hline & & long interruption & 3 \\
\hline & & external noises & 1 \\
\hline & & difficult words & 5 \\
\hline & & more quiet & 10 \\
\hline & Future directions & environment & \\
\hline & & easier words & 5 \\
\hline & & higher motivation & 1 \\
\hline
\end{tabular}

Informal assessment of reading ability: The assessment included 3 reading issues: reading syllables, reading familiar from the intervention words and reading unfamiliar words. The student wasn't able to read syllables with ligatures or complex phonetic combinations. However, she managed to read simple syllables with the consonant-vowel sequence, without pronouncing each phoneme separately first.

As for the intervention's reading material, the words were given to the student in a random sequence without any thematic classification. She managed to read 45/65 words (69\%), most of which had two or three syllables and simple c-v sequence (75.5\%) and only few had two syllables and ligatures or other phonemic combinations and clusters (24.5\%). She failed in reading words with 4 syllables, words with complicated phonemic combinations or clusters and words with abstract concepts, as well as sensory verbs.

The student managed to read some of the unfamiliar words given, those with two syllables and simple c-v sequence. Obviously, she is at the stage of acquiring decoding abilities for simple words, while the quantity of the syllables, as well as their intricacy and the abstract or unknown meaning of the word accumulate the difficulties. 
MULTILINGUAL ACADEMIC JOURNAL OF EDUCATION AND SOCIAL SCIENCES

Vol. 1 No. 1, 2013, E-ISSN: 2308-0876 ¿ 2013 KWP

Standardized screening test of identifying reading difficulties: For this measurement was implemented the standardized screening test, "Test of Identifying Reading Difficulties" (Porpodas et al., 2008), which was used before the intervention, so as the possible advancement in her reading abilities to be identified and recorded. Her general performance placed her again on the lower scale of reading skills, although phonological short-term memory skills increased 1 unit.

Table 8. Diagnostic reading chart (before and after the intervention), (Porpodas, 2008)

\begin{tabular}{|c|c|c|c|c|c|c|c|c|c|}
\hline \multirow{2}{*}{$\begin{array}{l}\text { Perfor } \\
\text { mance }\end{array}$} & \multirow[b]{2}{*}{ Units } & \multicolumn{2}{|c|}{$\begin{array}{l}\text { Reading } \\
\text { decoding }\end{array}$} & \multicolumn{2}{|c|}{$\begin{array}{c}\text { Reading } \\
\text { comprehension }\end{array}$} & \multicolumn{2}{|c|}{$\begin{array}{c}\text { Phonologic } \\
\text { al } \\
\text { awareness }\end{array}$} & \multicolumn{2}{|c|}{$\begin{array}{c}\text { Phonological } \\
\text { short-term } \\
\text { memory }\end{array}$} \\
\hline & & $\begin{array}{c}\text { Rea } \\
\text { din } \\
\text { g } \\
\text { syll } \\
\text { abl } \\
\text { es }\end{array}$ & $\begin{array}{c}\text { Rea } \\
\text { din } \\
\text { g } \\
\text { pse } \\
\text { udo } \\
\text { wor } \\
\text { ds }\end{array}$ & $\begin{array}{l}\text { Readin } \\
\text { g } \\
\text { senten } \\
\text { ces } \\
\text { and } \\
\text { matchi } \\
\text { ng } \\
\text { with } \\
\text { picture } \\
\text { s }\end{array}$ & $\begin{array}{l}\text { Reading } \\
\text { and } \\
\text { complet } \\
\text { e the } \\
\text { missing } \\
\text { word } \\
\text { into the } \\
\text { sentence }\end{array}$ & $\begin{array}{l}\text { Cutti } \\
\text { ng } \\
\text { pseu } \\
\text { do } \\
\text { wor } \\
\text { ds to } \\
\text { pho } \\
\text { nem } \\
\text { e }\end{array}$ & $\begin{array}{l}\text { Pho } \\
\text { nem } \\
\text { e } \\
\text { dele } \\
\text { tion }\end{array}$ & $\begin{array}{c}\text { Num } \\
\text { bers } \\
\text { sequ } \\
\text { ence } \\
\text { mem } \\
\text { ory }\end{array}$ & $\begin{array}{c}\text { Pseud } \\
\text { o } \\
\text { words } \\
\text { repeat } \\
\text { ing }\end{array}$ \\
\hline \multirow{8}{*}{$\begin{array}{l}\text { High } \\
\text { perfor } \\
\text { mance }\end{array}$} & 19 & - & - & - & - & - & - & - & - \\
\hline & 18 & - & - & - & - & - & - & - & - \\
\hline & 17 & - & _ & - & - & - & - & - & - \\
\hline & 16 & - & - & - & - & - & - & - & - \\
\hline & 15 & - & - & - & - & _ & - & - & - \\
\hline & 14 & - & - & - & - & _ & - & _ & - \\
\hline & 13 & - & _ & - & _ & _ & - & _ & - \\
\hline & 12 & - & - & - & - & - & - & - & - \\
\hline \multirow{5}{*}{$\begin{array}{l}\text { Mediu } \\
\quad \mathrm{m} \\
\text { perfor } \\
\text { mance }\end{array}$} & 11 & - & _ & - & - & _ & _ & - & - \\
\hline & 10 & - & - & - & - & - & - & - & - \\
\hline & 9 & - & - & - & - & - & - & - & - \\
\hline & 8 & - & - & - & - & - & - & - & - \\
\hline & 7 & - & - & - & - & - & - & - & - \\
\hline \multirow{3}{*}{$\begin{array}{l}\text { Low } \\
\text { perfor } \\
\text { mance }\end{array}$} & 6 & - & - & - & - & - & & & - \\
\hline & 5 & - & - & - & & 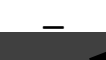 & & & \\
\hline & 3 & & 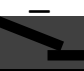 & & & $=$ & - & - & \\
\hline
\end{tabular}

Quantitative analysis: The intervention included 65 words: 18 simple two-syllable words (27.7\%), 17 simple three-syllable words (26.2\%), 18 two-syllable words with phonetic combination, like ligatures and clusters (27.7\%), 9 three-syllable words with phonetic combination, like ligatures and clusters (13.8\%) and 3 four-syllable words (4.6\%). The eight-yearold girl managed to read 45 words (69.2\%) while failing in 20 words (30.8). 
MULTILINGUAL ACADEMIC JOURNAL OF EDUCATION AND SOCIAL SCIENCES

Vol. 1 No. 1, 2013, E-ISSN: 2308-0876 @ 2013 KWP

A modified t-test was used for the statistical analysis of the results, which compares results between similar studies (Crawford \& Howell, 1998). Levy \& Antebi (2004) researched reading abilities of 17 children with WS, who succeeded in recognizing known words in $63 \%$. The student, who participated in the present study, succeeded in reading known words in $73 \%$.

$$
t=\frac{p_{\text {ind }}-p_{2}}{S_{2} \cdot \sqrt{\frac{N_{2}+1}{N_{2}}}}=\frac{0.73-0.63}{0.12 \cdot \sqrt{\frac{17+1}{17}}}=0.81
$$

As $d f=17-1=16$ and $p$-value $=0.21>0.005$, there is no statistical significant difference between Levy \& Antebi's study and the present. The girl's performance is similar to the performance other children with WS exhibited.

Additionally, the variables of the study, such as type word and reading success can be correlated. Reading success in simple two-syllable words is $18 / 18$, in simple three-syllable words is $15 / 17$, in two-syllable with phonetic combination, like ligatures and clusters is $8 / 18$, in threesyllable with phonetic combination, like ligatures and clusters is 4/9 and in four-syllable words is $0 / 3$. The correlation test between the two variables, the word type and the reading success has $p$-value $=0.000<0.005$ meaning that the two variables are correlated. In other words, the possibility of failing in reading increases, as the length of the word increases or its phonological content is complicated, by having ligatures or clusters.

\section{Discussion}

After considering previous studies related the most appropriate educational methods for children with WS, a reading intervention program for the eight-year-old girl with WS was designed and implemented. The intervention followed a 'top-down' approach of constructing the knowledge and combined elements from several methods, such as "holistic approach", "holistic-analytical method", "whole-word teaching". The student's performance was evaluated by using several methods, such as recording information on journals, informal assessment, as well as standardized screening test of reading ability and statistical analysis, in order valid inferences to be excluded.

The intervention proved to be successful, as the student exhibited progress in her reading abilities, although to a certain degree. Before the intervention, she could only read a few simple syllables (pronouncing separately each letter first), but no word, while after the intervention she was able to read all the simple syllables (without pronouncing separately each letter first), a large amount of the words she was taught through the intervention and some of the simple twosyllable words given.

The student encountered difficulties in long words, ligatures, complex phonological combinations, as well as phonological similarities of words, confirming the influence of the phonological factor (Laing et al., 2001; Levy \& Antebi, 2004; Mervis, 2009). Nevertheless, she didn't manage to read any unknown words, asserting the semantic factor (Barca et al., 2007; Pinheiro et al., 2010). However, the number of the unknown words, included in the interventional reading material was too small to enable us to generalize the results.

Although student's development was not obvious on standardized screening test, the light increase of her performance in phonological short-term memory issue confirms the cognitive strength of individuals with WS in that area (Brock, 2007; Mervis, 2009; Mervis et al., 
MULTILINGUAL ACADEMIC JOURNAL OF EDUCATION AND SOCIAL SCIENCES

Vol. 1 No. 1, 2013, E-ISSN: 2308-0876 @ 2013 KWP

2003; Pleh et al., 2003). Furthermore, the word reading was influenced by the passage of time, as the girl could finally read less words than previously, converging with the view that long-term memory is spared in WS (Rhodes et al., 2010). Statistical analysis of the case study indicated the positive impact of the intervention, since a certain degree of reading performance was recorded. Furthermore, the type of the word was found to be strongly correlated with the reading performance. It is also worth noting that phonological awareness has been strongly correlated with reading skills' development (Levy \& Antebi, 2004; Mervis, 2009), as high performance in phonological issues agree with high performance in reading pseudo words issues as well (Laing et al., 2001; Menghini et al., 2004).

In conclusion, the results of the study verified the influence of the phonological factor in reading and highlighted the holist approach as an appropriate way to develop reading and comprehension skills by using a multisensory way during the reading process, which also proved to be valuable in the construction of meaning. It is also worth noting that phonological awareness has been strongly correlated with reading skills' development (Levy \& Antebi, 2004; Mervis, 2009), as high performance in phonological issues agree with high performance in reading pseudo words issues, as well (Laing et al., 2001; Menghini et al., 2004).

The present study is limited in scope since it dealt with one case study of WS. For this purpose further research is needed to support the current results.

\section{References}

Barca, L., Ellis, A. W., \& Burani, C. (2007). Context-sensitive rules and word naming in Italian children. Reading and Writing. An Interdisciplinary Journal, 20, 495-509.

Becerra, A. M., John, A. E., Peregrine, E., Mervis, C. B. (2008). Reading abilities of 9-17-year-olds with Williams syndrome. Impact of reading method. Symposium on Research in Child Language Disorders, Madison, WI.

Brock, J. (2007). Language abilities in Williams syndrome. A critical review. Development and Psychopathology, 19, 97-127.

Forster, K. I., (1976). Accessing the mental lexicon. In RJ Wales \& EW Walker (Eds.) New approaches to language mechanisms (pp.257-287). Amsterdam. North Holland.

Georgas, D., Paraskevopoulos, I.N., Bezevegis, H., \& Giannitsas, N. (1998). Greek WISC-III. Athens. Psychometric Laboratory, University of Athens. [in Greek]

Crawford, J. R., \& Howell, D. C. (1998). Comparing an individual's test score against norms derived from small samples. The Clinical Neuropsychologist, 12(4), 482-486.

Herwegen, J. V., Farran, E., Annaz, D. (2011). Item and error analysis on Raven's Colored Progressive Matrices in Williams Syndrome. Research in Developmental Disabilities, 32, 9399.

Laing, E., Hulme, C., Grant, J., \& Karmiloff-Smith, A. (2001). Learning to read in Williams Syndrome. Looking beneath the surface of atypical reading development Journal of Child Psychology and Psychiatry, 42, 729-739.

Levy, Y., \& Antebi, V. (2004). Word reading and reading-related skills in Hebrew- speaking adolescents with Williams syndrome. Neurocase, 10, 444-451.

Marini, A., Martelli, S., Gagliardi, C., Fabbro, F., \& Borgatti R. (2010). Narrative language in Williams Syndrome and its neuropsychological correlates. Journal of Neurolinguistics, 23, 97-111. 
MULTILINGUAL ACADEMIC JOURNAL OF EDUCATION AND SOCIAL SCIENCES

Vol. 1 No. 1, 2013, E-ISSN: 2308-0876 @ 2013 KWP

Menghini, D., Verucci, L., \& Vicari, S. (2004). Reading and phonological awareness in Williams syndrome. Neuropsychology, 18, 29-37.

Mervis, C. B. (2009). Language and literacy development of children with Williams syndrome. Topics in Language Disorders, 29, 149-169.

Mervis, C. B., Robinson, B. F., Rowe, M. L., Becerra, A. M., \& Klein-Tasman, B. P. (2003). Language abilities of individuals who have Williams syndrome. In. Abbeduto L, editor. International Review of Research in Mental Retardation. Orlando, FL. Academic Press.

Mervis, C. B., \& Becerra, A. M. (2007). Language and communicative development in Williams syndrome. Mental Retardation and Developmental Disabilities, 13, 3-15.

Pinheiro, A.P., Galdo-Alvarez, S., Sampaio, A., Niznikiewicz, M., \& Goncalves, O.F. (2010). Electrophysiological correlates of processing in Williams syndrome. Research in Developmental Disabilities, 31, 1412-1425.

Pleh, C., Lukacs, A., \& Racsmany, M. (2003). Morphological patterns in Hungarian children with Williams syndrome and the rule debates. Brain and Language, 86, 377-383.

Porpodas, K., Diakogiorgi, KI., Dimakos, I., \& Karantzis, I. (2008). Test of detection and exploration of reading difficulties. Patras. Greek Ministry of Education and Religious funded by the EU. [in Greek]

Porter, M., \& Dodd, H. (2011). A longitudinal study of cognitive abilities in Williams Syndrome. Developmental Neuropsychology, 36(2), 255-272.

Raven, J. C., Court, J. H., \& Raven, J. C. (1990). Manual for Raven's progressive matrices and vocabulary scales - section 2. Colored progressive matrices. Oxford. Oxford Psychologists Press.

Rhodes, S. M., Riby, D. M., Park, J., Fraser, E., \& Campbell, L. E. (2010). Executive neuropsychological functioning in individuals with Williams syndrome. Neuropsychology, 48, 1216-1226.

Rossi, N. F., Sampaio, A., Goncalves, O. F., \& Giacheti, C. M. (2011). Analysis on speech fluency in Williams syndrome. Research in Developmental Disabilities, 32, 2957-2962.

Stojanovik, V. (2010). Understanding and production of prosody in children with Williams syndrome. A developmental trajectory approach. Journal of Neurolinguistics, 23, 112-126.

Stojanovik, V., \& Ewijk, L. (2008). Do children with Williams syndrome have unusual vocabularies? Journal of Neurolinguistics, 21, 18-34.

Stromme, P., Bjornstad, P. G., \& Ramstad, K. (2002). Prevalence estimations of Williams syndrome. Journal of Child Neurology, 17,269-271.

Temple, C. M., Almazan, M., \& Sherwood, S. (2002). Lexical skills in Williams syndrome. a cognitive neuropsychological analysis. Journal of Neurolinguistics, 15, 463-495.

Ypsilanti, A., Grouios, G., Alevriadou, A., \& Tsapkini, K. (2005). Expressive and receptive vocabulary in children with Williams and Down syndromes. Journal of Intellectual Disability Research, 49, 353-364.

Anastasia Alevriadou is Associate Professor of Psychology (emphasis in developmental disabilities) at the University of University of Western Macedonia, Greece. She holds a Master of Science and Ph.D. in Cognitive Psychology, Department of Psychology, Aristotle University of Thessaloniki, Greece. She has been on a fellowship at Ohio State University, Department of Developmental Disabilities, under the supervision of Dr. Aman (2007) and at John's Hopkins 
MULTILINGUAL ACADEMIC JOURNAL OF EDUCATION AND SOCIAL SCIENCES

Vol. 1 No. 1, 2013, E-ISSN: 2308-0876 @ 2013 KWP

University, Cognitive Science Department, under the supervision of Dr. McLoskey (1999). She is also Visiting Professor at the University of Cyprus. She has published 2 books, and 80 articles in international and Greek journals. She has participated in more than 60 International and National Conferences.

Maria Massi is a teacher of special education. She holds a Master degree in Educational Studies, with research interests in issues related to special education and young children. She has participated in various projects and conferences. 